\title{
KADAR KLORIDA SERUM PADA LATIHAN FISIK INTENSITAS SEDANG MAHASISWA FAKULTAS KEDOKTERAN UNIVERSITAS SAM RATULANGI
}

\author{
Roy Johannes \\ Diana S. Purwanto \\ Stefana H. M. Kaligis \\ Bagian Biokimia Fakultas Kedokteran Universitas Sam Ratulangi Manado
}

\begin{abstract}
Chloride as the major anion in the extracellular fluid plays a role in maintaining fluid and electrolyte balance. One of the factors that influence the levels of serum chloride is sweating during physical exercise. This study aimed to determine the differenceof serum chloride levels before and after moderate intensity exercise in the students of Faculty of Medicine year 2010 Sam Ratulangi University. This is a pre-exsperimental research with pretest and posttest design with 30 students as samples. The samples were chosen using purposive sampling method and the results were analyzed using paired-sample t-test. The results showed the average levels of serum chloride before and after moderate intensity exercise are 106,10 mEq/L and 107,37 mEq/L while paired-sample t-test significance value (p) is 0,000 . From the results can be concluded that there is a significant differences in serum chloride levels before and after moderate intensity exercise in the students of Faculty of Medicine year 2010 Sam Ratulangi University.
\end{abstract}

Keyword:serum chloride, moderate intensity exercise, student of Faculty of Medicine Sam Ratulangi University

\begin{abstract}
Abstrak: Klorida sebagai anion utama dalam cairan ekstraselular berperan dalammemelihara keseimbangan cairan dan elektrolit. Salah satu faktor yang mempengaruhi kadar klorida serum yaitu keluarnya keringat saat melakukan latihan fisik. Tujuan penelitian ini untuk mengetahui perbedaan kadar klorida serum sebelum dan sesudah latihan fisik intensitas sedang pada mahasiswa Fakultas Kedokteran Universitas Sam Ratulangi angkatan 2010. Penelitian ini merupakan penelitian pre-eksperimental dengan pretest-posttest design, dengan jumlah sampel 30 orang. Sampel penelitian dipilih dengan purposive sampling dan dianalisis dengan uji t berpasangan. Hasil yang diperoleh menunjukkan bahwa rata-rata kadar klorida serum sebelum melakukan latihan fisik intensitas sedang adalah 106,10mEq/L, sedangkan rata-rata kadar klorida serum sesudah melakukan latihan fisik intensitas sedang adalah 107,37 $\mathrm{mEq} / \mathrm{L}$. Nilai signifikansi uji t berpasangan pada penelitian ini adalah $\mathrm{p}=0,000$. Dari penelitian ini dapat disimpulkan bahwa terdapat perbedaan signifikan kadar klorida serum sebelum dan sesudah latihan fisik intensitas sedang pada mahasiswa Fakultas Kedokteran Universitas Sam Ratulangi Angkatan 2010.
\end{abstract}

Kata kunci: klorida serum, latihan fisik intensitas sedang, mahasiswa Fakultas Kedokteran Universitas Sam Ratulangi 
Klorida merupakan salah satu elektrolit penting dalam tubuh. Klorida sebagai anion utama dalam cairan ekstraselular berperan dalam menjaga homeostasis dalam tubuh. ${ }^{1}$ Klorida diekskresikan melalui urin dan keringat. Keringat mengandung 90-95\% air, juga mengandung mineral yang bervariasi yang dapat dipengaruhi berbagai faktor tergantung aktivitas fisik yang dilakukan. ${ }^{2}$

Keringat berlebih ketika melakukan latihan fisik dapat menyebabkan dehidrasi sehingga dapat mempengaruhi kadar klorida serum. ${ }^{3}$ Kekurangan klorida atau hipokloremia menyebabkan terjadinya spasme dan hipertonus otot sehingga seseorang dapat mengalami kram dan kelemahan otot saat melakukan latihan fisik. Kelebihan klorida atau hiperkloremia dapat menimbulkan kelemahan, letargi, dan pernapasan kussmaul. Penggantian cairan tubuh sangat penting untuk mencegah kehilangan elektrolit saat melakukan latihan fisik. ${ }^{4}$

Latihan fisik didefinisikan sebagai sub-kelompok aktivitas fisik berupa gerakan tubuh yang terencana, terstruktur, dan repetitif untuk memperbaiki atau memelihara satu atau lebih komponen kebugaran fisik. ${ }^{5}$ Menurut World Health Organization (WHO) tahun 2008 secara global sekitar 31\% dari orang dewasa berusia 15 tahun ke atas yang kurang aktif secara fisik. ${ }^{6} \mathrm{Di}$ Indonesia berdasarkan hasil riset kesehatan daerah tahun 2007 prevalensi nasional kurang aktivitas fisik pada penduduk umur $>10$ tahun sebesar 48,2\%. Sebanyak 16 provinsi termasuk provinsi Sulawesi Utara mempunyai prevalensi kurang aktivitas fisik pada penduduk umur > 10 tahun. $^{7}$

Ketika melakukan latihan fisik kontraksi otot dan proses metabolisme tubuh akan menghasilkan peningkatan energi dan panas, cairan yang berada di dalam tubuh kemudian akan menjalankan fungsinya sebagai pengatur panas atau sebagai thermoregulator. Sebagai penghantar panas yang baik, air akan mengeluarkan kelebihan panas tubuh melalui keluarnya air keringat. ${ }^{8}$ Natrium dan klorida merupakan mineral dengan konsentrasi tertinggi yang terbawa keluar tubuh melalui kelenjar keringat. ${ }^{9}$

Penelitian Hazar et al dan Koc mengenai kadar klorida serum pada latihan fisik memberikan kesimpulan yang sama tetapi dalam pelaksanaannya kedua penelitian memiliki perbedaan. Subjek kedua penelitian atlet melakukan latihan fisik dengan intensitas berat tetapi berbeda pada tipe dan durasinya. ${ }^{10,11}$ Intensitas kedua latihan fisik dikelompokkan hanya berdasarkan tipe aktivitas yang dilakukan. Selain itu subjek kedua penelitian adalah altlet sehingga mucul ketertarikan penulis tertarik untuk meneliti bagaimana hasil yang didapatkan jika subjek penelitian bukan pada atlet yaitu pada mahasiswa.

Mahasiswa merupakan salah satu kelompok yang diketahui jarang melakukan latihan fisik atau hanya tergolong melakukan aktivitas fisik ringan dalam kesehariannya. Pernyataan tersebut didukung dengan penelitian yang dilakukan Irwan mengenai aktivitas fisik pada mahasiswa Fakultas Kedokteran Universitas Sam Ratulangi angkatan 2011 didapatkan 96,6\% responden tergolong memiliki aktivitas fisik ringan sehingga dari hal tersebut terdapat perbedaan tingkat aktivitas fisik antara mahasiswa dengan atlet. ${ }^{12}$

Berdasarkan uraian di atas timbul keinginan penulis melakukan penelitian untuk mengetahui gambaran kadar klorida serum sebelum dan sesudah latihan fisik intensitas sedang dan untuk mengetahui apakah terdapat perbedaan kadar klorida serum sebelum dan sesudah latihan pada mahasiswa Fakultas Kedokteran Universitas Sam Ratulangi angkatan 2010. Latihan fisik berupa latihan di atas treadmill dengan intensitas sedang yang diukur berdasarkan frekuensi denyut jantung maksimal. 


\section{HIPOTESIS}

1. $\mathrm{H}_{0}$ : tidak ada perbedaan kadar klorida serum sebelum dan sesudah latihan fisik intensitas sedang.

2. $\mathrm{H}_{\mathrm{a}}$ : terdapat perbedaan kadar klorida serum sebelum dan sesudah latihan fisik intensitas sedang.

\section{METODE PENELITIAN}

Penelitian ini adalah penelitian pra-eksperimen dengan pendekatan one group pretestposttest dan dilaksanakan di Manado selama bulan September 2013 - Januari 2014. Populasi ialah seluruh mahasiswa Fakultas Kedokteran Universitas Sam Ratulangi program studi pendidikan dokter umum angkatan 2010. Sampel penelitiandiambil dengan metode purposive sampling sebanyak 30 orang. Kriteria inklusi antara lain sehat, bukan atlet, bersedia ikut serta dalam penelitian. Kriteria eksklusi antara lain sedang sakit ketika latihan fisik dilakukan, mengonsumsi obat yang mempengaruhi kadar elektrolit darah, mengonsumsi makanan dan minuman 3-4 jam sebelum latihan dilakukan, melakukan latihan fisik pada hari pelaksanaan penelitian. Variabel yang dipakai adalah kadar klorida serum dan latihan fisik intensitas sedang.

Definisi operasional kadar klorida serum adalah hasil yang didapat dari pengambilan darah vena tanpa puasa yang diperiksa dengan alat AVL 9180 electrolyte analyzer dengan metode elektroda ion selektif dapat diklasifikasi normal adalah 96-111 mmol/L. Latihan fisik intensitas sedang yaitu latihan fisik dengan walking di atas treadmill dengan target denyut jantung (HR) 64 - 76\% dari denyut jantung maksimum (HRmax). Denyut jantung maksimum $\left(\mathrm{HR}_{\max }: 200\right.$ - umur), HR target $\left(64 \%-76 \% \mathrm{HR}_{\max }\right)$, batas bawah $\left(64 \% \mathrm{HR}_{\max }\right)$, batas atas $\left(76 \% \mathrm{HR}_{\max }\right){ }^{13,14}$

\section{Prosedur Pelaksanaan Penelitian}

Setiap subyek yang memenuhi kriteria inklusi dan eksklusi diminta untuk mengisi inform consent dan mengikuti prosedur penelitian. Pelaksanaan penelitian terdiri dari pengambilan darah pertama, pemanasan selama 5 menit, peregangan selama 5 menit, latihan inti selama 30 menit, pengambilan darah kedua, dan pendinginan selama 5 menit. Latihan fisik inti berupa walking di atas treadmilldan heart rate dipertahankan sesuai target yang akan dicapai berdasarkan umur. Pengambilan darah dilakukan oleh laboran. Pengambilan darah dilakukan sebanyak duakali, pengambilan pertama sebelum melakukan latihan fisik dan pengambilan kedua sesegera setelah latihan inti selesai dilakukan. Pemeriksaan kadar klorida serum menggunakan metode ISE (Ion Selective Electrode).

\section{Pengolahan Data}

Data diolah menggunakan program SPSS (Statistical Package for the Social Sciences) dianalisa univariat (mean, median,standar deviasi, min, max) dan bivariat dengan uji $t$ berpasangan (paired t-test).

\section{HASIL}

\section{Karakteristik Responden}

Berdasarkan kategori umur, frekuensi umur yang terbanyak adalah umur 21 tahun sebanyak 15 orang (50\%), kemudian umur 20 tahun sebanyak 13 orang (43,3\%), dan frekuensi umur terkecil adalah umur 22 dan 23 tahun masing-masing 1 orang (3,3\%). 


\section{Analisis Univariat}

Hasil analisis univariat kadar klorida serum sebelum latihan fisik intensitas sedang didapatkan rata-rata 106,10 mEq/L, median $106 \mathrm{mEq} / \mathrm{L}$, standar deviasi 1,668; nilai terendah $102 \mathrm{mEq} / \mathrm{L}$, dan nilai tertinggi $109 \mathrm{mEq} / \mathrm{L}$. Untuk kadar klorida serum sesudah latihan fisik intensitas sedang didapatkan rata-rata $107,37 \mathrm{mEq} / \mathrm{L}$, median $107 \mathrm{mEq} / \mathrm{L}$, standar deviasi 1,608; nilai terendah $104 \mathrm{mEq} / \mathrm{L}$, dan nilai tertinggi $112 \mathrm{mEq} / \mathrm{L}$ (Tabel 1).

Tabel 1. Analisis Univariat

\begin{tabular}{|c|c|c|c|}
\hline & & SebelumLatihan & SesudahLatihan \\
\hline \multirow{2}{*}{$\mathrm{N}$} & Valid & 30 & 30 \\
\hline & Missing & 0 & 0 \\
\hline \multicolumn{2}{|c|}{ Mean } & 106,10 & 107,37 \\
\hline \multicolumn{2}{|c|}{ Median } & 106,00 & 107,00 \\
\hline \multicolumn{2}{|c|}{ Std. Deviation } & 1,668 & 1,608 \\
\hline \multicolumn{2}{|c|}{ Minimum } & 102 & 104 \\
\hline \multicolumn{2}{|c|}{ Maximum } & 109 & 112 \\
\hline
\end{tabular}

\section{Analisis Bivariat}

Analisis bivariat dilakukan uji parametrik yaitu uji t berpasangan. Sebelumnya dilakukan uji Shapiro-Wilk untuk mengetauhi data berdistribusi normal atau tidak. Hasil uji Shapiro-Wilk didapatkan nilai p sebelum latihan fisik adalah 0,94 dan nilai p sesudah latihan fisik adalah 0,152 (Tabel 2). Nilai p sebelum dan sesudah latihan fisik $>0,05$ sehingga kedua data diasumsikan berdistribusi normal. Dilanjutkan uji t berpasangan dan diperoleh nilai p 0,000 < 0,001 mengindikasikan bukti yang kuat untuk menolak hipotesis nul dan menerima hipotesis alternatif yaitu terdapat perbedaan kadar klorida serum sebelum dan sesudah latihan fisik intensitas sedang (Tabel 3).

Tabel 2. Tes Normalitas Data

\begin{tabular}{lrrr}
\hline & \multicolumn{3}{c}{ Shapiro-Wilk } \\
& Statistic & df & \multicolumn{1}{c}{ Sig } \\
\hline SebelumLatihan &, 940 & 30 &, 094 \\
SesudahLatihan &, 948 & 30 &, 152 \\
\hline
\end{tabular}

Tabel 3. Uji t Berpasangan

\begin{tabular}{|c|c|c|c|c|c|c|}
\hline & & Mean & $\begin{array}{c}\text { Std. } \\
\text { Deviation } \\
\end{array}$ & $\mathrm{t}$ & $\mathrm{df}$ & Sig. (2-tailed) \\
\hline Pair 1 & $\begin{array}{l}\text { SebelumLatihan - } \\
\text { SesudahLatihan }\end{array}$ & $-1,267$ & 1,530 & $-4,535$ & 29 & ,000 \\
\hline
\end{tabular}




\section{BAHASAN}

Penelitian ini mengambil 30 sampel dan hasil analisis laboratorium kadar klorida serum sebelum latihan fisik didapati 30 sampel dalam batas normal. Sesudah latihan fisik didapati 29 sampel memiliki kadar klorida serum dalam batas normal dan didapati satu sampel meningkat di atas batas normal atau termasuk hiperkloremia. Hiperkloremia dapat menyebabkan kelemahan, letargi, serta pernapasan cepat dan dalam.

Hasil analisis didapatkan peningkatan kadar klorida serum sebelum latihan fisik (106,10 mEq/L) dibandingkan dengan sesudah latihan fisik (107,37 mEq/L). Hasil uji statistik menunjukkan ada perbedaan signifikan kadar klorida serum antara sebelum dan sesudah latihan fisik intensitas sedang ( $\mathrm{c} 0$,001). Hal ini sesuai dengan penelitian yang dilakukan Mursyida mengenai pengaruh aktivitas fisik aerobik dan anaerobik terhadap kadar elektrolit darah yang menyimpulkan terdapat perbedaan bermakna kadar klorida sebelum dan sesudah latihan fisik aerobik maupun anaerobik. ${ }^{3}$ Berbeda dengan penelitian Hazar, dkk dan Koc mengenai kadar klorida sebelum dan sesudah latihan fisik yang keduanya menyimpulkan tidak ada perbedaan signifikan kadar klorida serum sebelum dan sesudah latihan fisik.

Terdapat perbedaan pada sampel yang di teliti. Penelitian Hazar dan Koc mengambil sampel atlet sedangkan penelitian Mursyida dan peneltian yang dilakukan peneliti mengambil sampel mahasiswa. Salah satu kriteria inklusi penelitian ini ialah bukan atlet. ${ }^{3,10,11}$

Kelenjar keringat kebanyakan atlet sudah mengalami aklimatisasi panas akibat latihan fisik yang rutin dilakukan. Aklimatisasi panas merupakan proses adaptasi berupa peningkatan respon fisiologis tubuh akibat latihan berulang terhadap suatu lingkungan baru yang akan dimasukinyaterutama panas. Aklimatisasi panas pada kelenjar keringat menyebabkan jumlah kehilangan garam dalam keringat lebih sedikit dibandingkan dengan yang tidak beraklimatisasi. Aklimatisasi kelenjar keringat merupakan hasil peningkatan sekresi aldosteron oleh korteks adrenal. Aldosteron selanjutnya mempengaruhi kelenjar keringat untuk meningkatkan reabsorpsi natrium klorida dari keringat sebelum dikeluarkan dari tubulus kelenjar keringat ke permukaan kulit. Sehingga proses aklimatisasi kelenjar keringat pada atlet dapat mempengaruhi kadar klorida serum terutama sesudah latihan fisik dilakukan. $^{15}$

Walaupun hasil analisis data menunjukkan perbedaan tetapi pemeriksaan kadar klorida serum sebelum dan sesudah latihan fisik yang dilakukan oleh Hazar dan Koc memiliki persamaan dengan hasil yang peneliti dapatkan. Rata-rata kadar klorida serum sesudah latihan fisik meningkat dibandingkan dengan kadar klorida serum sebelum latihan fisik dilakukan. $^{10,11}$

Hal tersebut terjadi karena ketika terjadi peningkatan panas di dalam tubuh baik dari metabolisme energi ataupun hasil dari kontraksi otot saat melakukan latihan fisik, air yang berada di dalam sirkulasi aliran darah akan menyerap panas dan mengeluarkannya pada permukaan kulit melalui kelenjar keringat. Keringat mengandung 90-95\% air, juga mengandung mineral yang bervariasi yang dapat dipengaruhi berbagai faktor tergantung aktivitas fisik yang dilakukan. ${ }^{2}$ Keluarnya keringat saat melakukan latihan fisik jika tidak diimbangi dengan konsumsi cairan maka air yang keluar dari cairan intertisial atau plasma darah akan menyebabkan terjadinya peningkatan konsentrasi elektrolit di dalam cairan ekstraselular yang salah satunya merupakan klorida.

Peningkatan konsentrasi elektrolit ini kemudian akan menyebabkan terjadinya perbedaan konsentrasi antara cairan intraselular dan cairan ekstraselular. Melalui proses osmosis, air kemudian akan berpindah dari cairan yang memiliki konsentrasi air tinggi menuju cairan yang memiliki konsentrasi air rendah yaitu berpindah dari dalam sel menuju ke luar sel. Jika proses ini dibiarkan dalam jangka waktu yang lama tanpa konsumsi cairan yang 
cukup, sel-sel di dalam tubuh akan mengalami dehidrasi. ${ }^{8}$ Dehidarasi merupakan defisiensi cairan tubuh yang ditandai dengan hiperosmotik hipovolemia. Dehidrasi mengakibatkan perubahan-perubahan fisiologis pada tubuh manusia yaitu meningkatnya prosentase $\mathrm{NaCl}$ dalam ekstrasel dan menurunkan volume plasma darah. ${ }^{3}$

Ketika sel-sel mengalami dehidrasi, proton yang terdapat di dalam mitokondria akan mengalami gangguan akibat dari peningkatan konsentrasi ion yang terjadi di dalam sel. Gangguan pada gradien proton ini akan menghambat laju produksi ATP (Adenosin Triphosphat) sehingga mengganggu proses kontraksi dan relaksasi otot. ${ }^{8}$

Keterbatasan dalam penelitian ini adalah jumlah sampel yang diteliti belum maksimal. Peneliti hanya mengambil jumlah sampel minimal dari desain penelitian eksperimental. Terdapat pula keterbatasan lain pada saat pelaksanaan penelitian yaitu suhu ruangan tempat pelaksanaan latihan fisik tidak dapat dijaga tetap stabil. Diketahui bahwa suhu lingkungan merupakan salah satu faktor yang mempengaruhi jumlah cairan yang hilang melalui keringat.

\section{KESIMPULAN}

Berdasarkan penelitian yang telah dilakukan pada mahasiswa Fakultas Kedokteran Universitas Sam Ratulangi program studi pendidikan dokter umum angkatan 2010 dapat ditarik tiga kesimpulan yaitu pertama, kadar klorida serum sebelum dan sesudah latihan fisik intensitas sedang dalam batas normal. Kedua,terdapat peningkatan rata-rata kadar klorida serum sesudah latihan fisik intensitas sedang $(107,37 \mathrm{mEq} / \mathrm{L})$ dibandingkan sebelum latihan $(106,10 \mathrm{mEq} / \mathrm{L})$. Ketiga, terdapat perbedaan signifikan $(\mathrm{p}<0,001)$ kadar klorida serum sebelum dan sesudah latihan fisik intensitas sedang.

\section{DAFTAR PUSTAKA}

1. Wilson LM. Keseimbangan cairan dan elektrolit serta penilaiannya. In: Hartanto H, Susi N, Wulansari P, Mahanani DA, editor bahasa Indonesia. Patofisiologi Konsep Klinis Proses-Proses Penyakit (Edisi 6). Pendit BU, Hartanto H, Wulansari P, Mahanani DA, alih bahasa. Jakarta: EGC, 2005; p.308-18.

2. Makfoeld D, Marseno DW, Hastuti P, Anggrahini S, Raharjo S, Sastrosuwignyo S, et al. Kamus istilah pangan dan nutrisi. Yogyakarta:Kanisius,2002;p.177.

3. Wadud MA. Pengaruh aktivitas fisik aerobik dan anaerobik terhadap kadar ADH dan elektrolit darah. Politeknik Kesehatan Palembang. 2013;1:1-7.

4. William L, Wilkins. Fluids \& electrolytes. Brener TH, Nale P, editors. Norristown: Wolter Kluwer, 2007;p.151-8.

5. Gibney MJ, Margetts BM, Kearney JM, Arab L, editors. Gizi kesehatan masyarakat. Hartanto A, alih bahasa. Jakarta: EGC, 2005;p.103.

6. World Health Organization. Prevalence of insufficient physical activity [homepage on the internet]. Nodate [cited 2013 Sep 25]. Available from: http://www.who.int/gho/ncd/risk_factors/physical_activity_text/en/.

7. Riset kesehatan daerah tahun 2007. Jakarta Desember 2008. Hal.19. 
8. Irawan MA. Konsumsi cairan dan olahraga [homepage on the internet]. 2007 [cited 2013 Sep 11]. Available from: http://www.pssplab.com/journal/02.pdf.

9. Irawan MA. Konsumsi cairan tubuh, elektrolit, dan mineral [homepage on the internet]. 2007 [cited 2013 Sep 11]. Available from: http://www.pssplab.com/journal/01.pdf.

10. Hazar M, Sever O, Gurkan CA, Er FN, Erol M. Physiologic responses of macro element to maximal aerobic exercise in male and female footballers.Life Sci J. 2013;10(6):734-7.

11. Koc H. The Effect of acute excercises on blood electrolyte values in handball players. Afr. J. Pharm. 2011;4(1):93-7.

12. Thirtayasa IH. Hubungan antara aktivitas fisik dengan status gizi mahasiswa angkatan 2011 Program Studi Pendidikan Dokter Universitas Sam Ratulangi [skripsi]. Manado:Universitas Sam Ratulangi;2012.

13. Engka JNA, Soempono B, Suwono. Pengaruh penambahan intensitas latihan terhadap ambilan oksigen maksimum (VO2 maks) kajian pada anggota klub jantung sehat.

Majalah sains kesehatan. 2003;16(1):173-90.

14. Thompson WR, Gordon NF, Pescatello LS, editors. ACSM's Guidelines for Exercise Testing and Prescription. Atlanta: Wolters Kluwer, 2009;p.6.

15. Guyton AC, Hall JE. Buku Ajar Fisiologi Kedokteran (Edisi 11). Rachman LY, Hartanto H, Novrianti A, Wulandari N, editor bahasa Indonesia. Jakarta: EGC, 2007; p.307-10, 937-43, 1121-22. 